\title{
The Use of the Legend of Sleepy Hollow in EFL Classrooms
}

\author{
Gabriely Diniz ${ }^{1 *}$ \\ ${ }^{1}$ State University of Paraiba, Brazil \\ *Corresponding author: Gabriely Diniz: gabrielycqdiniz@gmail.com
}

\section{OPEN ACCESS}

Citation: Diniz G. (2020) The Use of the Legend of Sleepy Hollow in EFL Classrooms. Open Science Journal 5(3)

Received: $6^{\text {th }}$ April 2020

Accepted: $25^{\text {th }}$ June 2020

Published: $28^{\text {th }}$ July 2020

Copyright: (C) 2020 This is an open access article under the terms of the Creative Commons Attribution License, which permits unrestricted use, distribution, and reproduction in any medium, provided the original author and source are credited.

Funding: The author(s) received no specific funding for this work

Competing Interests: The author has declared that no competing interests exists.

\begin{abstract}
:
Considering the value of literary texts as authentic language materials to provide real uses of lexical and syntactic items and interesting subjects for students to connect better with the language. In addition, taking in account the characteristic of light horror presented by Irving in the story proves adaptable for different levels and ages, we should use this factor to attract the student for the subjects of our planning. As the use of literature in language lessons stimulates mostly the use of three skills: reading, writing and speaking. This short article collects activities prepared to help EFL students to advance in these areas, and, by the addition of the video as a resource, which presents a context of leisure and entertainment, and could modify student's posture and expectations in relation to its use (MORÁN, 1995).
\end{abstract}

Keywords: Sleepy hollow, Washington Irvin, EFL teaching

\section{Introduction}

Washington Irving (1783-1859) is an American essayist well-known for writing The Legend of Sleepy Hollow and Rip Van Winkle, considered America's first stories. His works are present in compendiums of Halloween stories and Gothic Literature. In this essay, we focus on The Legend of Sleepy Hollow and the story of Ichabod Crane, a superstitious schoolmaster who comes to Sleepy Hollow, a city haunted by a Headless Horseman. There, Crane falls in love with the wealthy Katrina Van Tassel and fights for her hand with the notorious Abraham Van Brunt (or Brom Bones). However, the story does not go well for Ichabod who is ambushed by his rival and killed by the Horseman.

This American story is influential to culture nowadays, considering its connection with Halloween and Christmas as we know. According to Nituama (2016), there is a belief that during Halloween the veil between the world of the dead and the living becomes thinner and it is possible for spirits - like the 
Headless Horseman - to cross over and visit the actual city of Sleepy Hollow, located in the New York state. Also, the description of Christmas presented by Washington Irving in many of his works and the physical characterization of Santa Claus presented in The Legend of Sleepy Hollow influenced the America's version of Santa

According to Violetta-Irene (2015, p. 74) Literature and language are strictly related. As Literature is "constituted by language and it represents one of the most recurrent uses of language", which means that Literature is a good source of grammar rules and rich examples of language use, because it provides genuine samples of language and wide range of styles, text types and registers.

Also, the literary text has multiple interpretations, which means that learners can have different opinions of the same text and it can lead to "real, motivated interaction with the text, with the fellow students and with the teacher" (VIOLETTA-IRENE, 2015, p. 75). Regarding to the author, the use of Literature in the classroom plays an important role in the formation of the student's critical thinking because it opens new points of view to them and stimulates the cultivation of critical abilities. Also, the literary text requires a personal response and invites the learner to produce their own experiences.

Students are always worried about the amount of work they have to bring home, so the use of short stories such as The legend of Sleepy Hollow, takes away their fear of reading. As reported by Violetta-Irene (2015, p.76), short stories have lots of benefits as its character of being applied more frequently, malleability on usage in different courses and levels, and being a compressed text. These qualities help the students to get in contact with plenty of information within a few words.

We consider here the value of literary texts as authentic language materials to provide real uses of lexical and syntactic items and interesting subjects for students to connect better with the language. In addition, taking in account the characteristic of light horror presented by Irving in the story proves adaptable for different levels and ages, we should use this factor to attract the student for the subjects of our planning.

The use of Literature in language lessons stimulates mostly the use of three skills: reading, writing and speaking. This essay collects activities prepared to help EFL students to advance in these areas, and, by the addition of the video as a resource, which presents a context of leisure and entertainment, it could modify student's posture and expectations in relation to its use (MORÁN, 1995).

The activities below work with comparison between the literary text and different video resources such as animation, television series and movie, to explore the language features for appearance. Before these activities it is important to work with basic vocabulary, warm up activities, and a possible contextualization with Halloween or Christmas, as presented by Nituama (2016).

As a first approach, we suggest a work of comparison between the description of the protagonist Ichabod Crane in the literary text and its appearance in the Disney animation called The Adventures of Ichabod and the Mr. Toad (1949) by Algar \& Geronimi.

Observe the description of Crane presented by Washington Irving:

He was tall, but exceedingly lank, with narrow shoulders, long arms and legs, hands that dangled a mile out of his sleeves, feet that might have served for shovels, and his whole frame most loosely hung together. His head was small, and flat at top, with huge ears, large green glassy eyes, and a long snipe nose, so that it looked like a weather-cock, perched upon his spindle neck, to tell which way the wind blew. To see him striding along the profile of a hill on a windy day, with 
his clothes bagging and fluttering about him, one might have mistaken him for the genius of famine descending upon the earth, or some scarecrow eloped from a corn-field. (IRVING, 2020, p. 48)

As the citation above possesses complex vocabulary, it is important to work in pairs or small groups, and use dictionaries or online translators to better understanding it. However, instead of delivering the vocabulary for students, the teacher should ask them to search the new words on the internet and draw their description of Ichabod. After this, the teacher can play the animation for students to compare their drawings with.

According to the American Film Institute (AFI) website the Disney animation The Adventures of Ichabod and the Mr. Toad is composed by two segments: the story of The Wind and the Willows by Kenneth Grahame, and The Legend of Sleepy Hollow by Irving, which can be found separately. Observe the synopsis of the second part:

The schoolteacher Ichabod Crane, who lives in Sleepy Hollow, New York, in the late 1800s. An unusual, superstitious man, Ichabod becomes infatuated with beautiful heiress Katrina van Tassel. Ichabod's chief rival for Katrina's affections is bully Brom Bones, who is extremely annoyed by the attention Katrina bestows on the skinny Ichabod. At the van Tassels' annual Halloween frolic, Ichabod and Brom dance feverishly to capture Katrina's favor, and when it appears that Ichabod will win, Brom tells the chilling story of the Headless Horseman in order to scare his superstitious competitor. At the party's end, a subdued Ichabod rides home on his horse, and as Brom's story echoes in his head, the shadows and scary noises of the forest become all the more upsetting. Suddenly, Ichabod sees the Headless Horseman astride his fiery steed, riding madly behind him. Ichabod and his terrified nag race toward a covered bridge, which must be crossed in order to escape the fiend, but their fright turns them around and they run straight into the horseman. Finally turning his horse the right direction, Ichabod reaches the bridge, but the horseman throws a flaming pumpkin head at him. The next morning, all that can be found at the site of the mysterious proceedings is Ichabod's hat and a shattered pumpkin. (AMERICAN FILM INSTITUTION, 2017)

For this part, the teacher can choose between reproducing the entire animation or scenes of it which correspond to the descriptions of Crane. As for the drawing activity, the educator must look for alternatives that fit his/her classroom profile and age range, such as substituting the activity for a discussion or composition for example.

In other proposal, the teacher plays the first episode of the television series Sleepy Hollow (2013) and asks the students to pay attention to the characters. Then, he/she divides them in groups and delivers descriptions of Ichabod Crane, Katrina Van Tassel and Brom Van Brunt without the name of the characters. After reading and researching for the vocabulary, students must match the descriptions with the characters portrait on the episode.

This kind of activity makes the students reflect about divergences between the synopsis of Sleepy Hollow and the actual plot of The Legend of Sleepy Hollow. Analyze the synopsis.

During the American War of Independence, insurgent Ichabod Crane, an English-born professor and civil rights pioneer, is among the pile of victims of a headless, ax-wielding Redcoat. Two centuries later, both are resurrected when their graves are disturbed. Sheriff August Corbin, whose county includes Sleepy Hollow village, is among the latest axed victims. However he leaves notes which are found by his headstrong deputy, lieutenant Abbie Mills, and the arrested, 
fascinating Ichabod, whom captain Irving orders to be evaluated in a psych ward. Ichabod gets visits from the ghost of his wife Katrina, who reveals being a good witch from an order fighting the evil one in league with the four riders of the Apocalypse, which includes Death, in the shape of the Redcoat. (IMDB, 2020)

As third and last suggestion, the teacher can reproduce Sleepy Hollow (1999) by Tim Burton and work with the summary of the tale and selected parts of it such as the description of Ichabod - presented in the activity above- and Abraham Van Brunt. Therefore, the teacher may ask the students to point the main differences between: i) the main plot and the profession of the characters, ii) appearance of Ichabod Crane and Brom Van Brunt, iii) the resolution of the story. Later, they should create a different ending for The Headless Horseman story.

Pay attention to the synopsis of Sleepy Hollow provided by IMDb's website and the description of Abraham provided in the literary text.

In 1799, New York City police constable Ichabod Crane is dispatched by his superiors to the Hudson Highlands hamlet of Sleepy Hollow, to investigate a series of brutal slayings in which the victims have been found beheaded. A frequent user of new, though so far unproven investigative techniques such as finger-printing and autopsies, Crane arrives in Sleepy Hollow armed with his bag of scientific tools only to be informed by the town's elders that the murderer is not of flesh and blood, rather a headless supernatural warrior from beyond the grave who rides at night on a massive black steed. Crane does not believe them and begins his own investigation, until he comes face to "face" with the Headless Horseman. Boarding a room at the home of the town's richest family, the Van Tassels, Crane develops an attraction to their daughter, the mysterious Katrina, even as he is plagued by nightmares of his mother's horrific torture under his zealous preacher father when he was a child. Delving further into the mystery with the aid of the orphaned Young Masbeth, whose father was a victim of the Horseman, Crane discovers within the Western Woods both the Horseman's entry point between this world and the beyond, the gnarled Tree of the Dead with the heads of his victims within, and his grave. (IMDB, 2020)

Brom Van Brunt, the hero of the country round, which rang with his feats of strength and hardihood. He was broad-shouldered and double-jointed, with short curly black hair, and a bluff, but not unpleasant countenance, having a mingled air of fun and arrogance. From his Herculean frame and great powers of limb, he had received the nickname of BROM BONES, by which he was universally known. He was famed for great knowledge and skill in horsemanship, being as dexterous on horseback as a Tartar. (IRVING, 2020)

In preparation to the activities suggested above, it is important to work with the author's biography and relevant vocabulary before or try to activate students' previous knowledge of body parts and adjectives. Also, it is important to ask the students to look for the unknown words on the web instead of providing a vocabulary chart. This way they can feel more connected to the story and get interested in further researches at home.

Although the adaptation the plot proved to be different from the Washington Irving's original text, these differences are able to develop students' critical thinking towards the literary text and videos, which can enhance the interest in the subject of pedagogical planning and classic Literature. Also, the contextualization of The Legend of Sleepy Hollow to Halloween can increase students' interest in the subject and promote a different approach to this common theme in EFL courses. 


\section{References:}

Irving, Washington. The Legend of Sleepy Hollow. Bauer Books, 2020.

Morán, José Manuel. "O Vídeo Na Sala De Aula." Comunicação \& Educação, no. 2, 1995, p. 27. doi:10.11606/issn.2316-9125.v0i2p27-35.

NiTuama, Shelley. Re-imagining "The Legend of Sleepy Hollow. 2016. . Access in november 29th of 2017

Violetta-Irene, Koutsompou. "The Use of Literature in the Language Classroom: Methods and Aims." International Journal of Information and Education Technology, vol. 5, no. 1, 2015, pp. 74-79., doi:10.7763/ijiet.2015.v5.479. 